\title{
4
}

\section{Metallophytes and Metallicolous Vegetation: Evolutionary Aspects, Taxonomic Changes and Conservational Status in Central Europe}

\author{
Henryk Baumbach \\ Friedrich-Schiller-Universität Jena \\ Germany
}

\section{Introduction}

Habitats with particular edaphic conditions such as metalliferous, serpentine or salt sites usually require special morphological, anatomical, and physiological adaptations of colonizing plants. Therefore, they often present specialized flora and vegetation and belong to the ecologically most interesting habitat types of Central Europe.

The vegetation of metalliferous soil sites is legally protected by European law (European Habitats Directive 92/43/EEC, Appendix I, habitat type 6130), national laws (e.g. in Germany by the Federal Nature Conservation Act, BNatSchG, § 30) and several federal state laws.

During the last decades the scientific focus has been on eco-physiological adaptations of metallophytes (for an overwiew see Baker et al., 2010), their community context and syntaxonomical evaluation (e. g. Libbert, 1930; Schwickerath, 1931; Koch, 1932; Schubert, 1953/54; Ernst, 1965, 1966, 1968, 1974; Koch \& Kuhn, 1989; Daniëls \& Geringhoff, 1994; Pott \& Hellwig, 2007), bio-geographical aspects (e. g. Schulz, 1912; Wein, 1926; Heimans, 1936; Schubert 1954a; Ernst, 1974), and their taxonomical status. Since the basic work of Schulz (1912) metallicolous ecotypes of vascular plants have received special attention in numerous publications, and several (endemic) taxa of dubious value have been described. Modern molecular methods (isozymes, DNA fingerprint and sequence analyses) allowed new insights into genetic differentiation of metallicolous populations, micro-evolutionary processes and the taxonomical treatment of several metallophyte taxa. Some scientific studies dealing with genetic differentiation of the character species of metallicolous vegetation (e. g. Minuartia verna, Silene vulgaris, Armeria maritima, Viola calaminaria, Cardaminopsis halleri, Thlaspi caerulescens) have shown that the taxonomic rank of some of them should be reconsidered. From this and due to new studies on vegetation composition syntaxonomical changes seem also to be necessary. Remarkable problems for the definition of habitat types may arise from this because the perception of the conservation authorities is focussed on the few character species of metalliferous vegetation.

In the first part of this chapter I will focus on this problem and discuss possible consequences for the conservation of metalliferous sites. In the second part of the chapter I will review the current situation of metalliferous sites and their vegetation in the former 
copper-shale mining region of Mansfeld and Sangerhausen (the eastern Harz Mountains foothills region, Saxony-Anhalt, Central Germany). Despite the legal protection and several conservation efforts, the number of metalliferous soil sites with their unique flora has decreased in several regions substantially. Therefore, I want to encourage a supra-regional conservation strategy for Central European metalliferous sites.

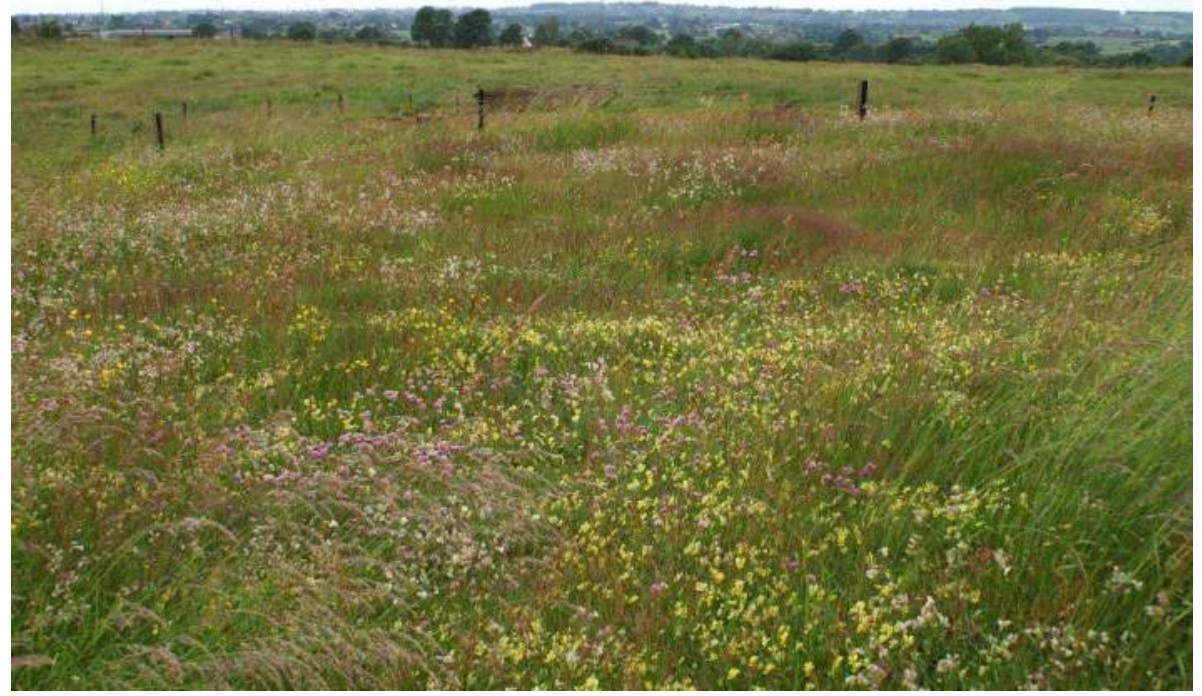

Fig. 1. Metallicolous vegetation with the character species Armeria maritima, Viola calaminaria, Minuartia verna and Silene vulgaris near Rabotrath (Belgium, photograph: H. Baumbach, June 2008).

\section{Types of metalliferous soil sites and their distribution in Central Europe}

Natural (primary) metalliferous soil sites are relatively rare in Central Europe and confined to the range of the Alps and to only few, small-area localities with particular geological and edaphic conditions in the lowlands (Ellenberg, 1996). Most of the recent metalliferous sites are secondary habitats shaped by ore mining and processing. They are concentrated in some mid-mountain ranges and their forelands in Germany (Saxony-Anhalt and Lower Saxony: Harz Mountains and foothills, North Rhine-Westphalia), and parts of Poland (Legnica, Olkusz), the Czech Republic (Pyšek \& Stočes, 1978; Pyšek \& Pyšek, 1988, 1989), Slovakia (Banasova, 1980), and Belgium (Simon, 1975; Dejonghe et al., 1993; Graitson et al., 2003). Tertiary sites can be subdivided into those whose genesis is a result of atmospheric deposition in the vicinity of metal smelters (Baumbach et al., 2007; Ernst et al., 2004) or alluvial deposition of metal-enriched substrates by sedimentation in river floodplains and on raised river banks. Well-known examples of this are the sites along the rivers downstream the mines and smelters with their ore crushing facilities in the Harz Mountains (Hellwig, 2002; Knolle, 1989), the Erzgebirge Mountains (Golde, 2011) and the Geul River 
valley in the Belgium-Netherlands border region (van der Ent, 2007). The flora and vegetation of metalliferous soils in the Alps is beyond the scope of this chapter, for an overview see Punz (1991, 1994, 2008) and Punz et al. (1990).

\section{Flora and vegetation}

\subsection{Flora}

\subsubsection{Metallophyte classification}

A classification of plant species colonizing metalliferous soils was introduced by Lambinon \& Auquier (1964). They differentiate between "metallophytes" (taxa found only on metalcontaminated soils) and "pseudo-metallophytes" (taxa found on both contaminated and uncontaminated soils within the same region, e. g. Silene vulgaris, Agrostis capillaris). Metallophyte taxa either grow exclusively on metalliferous soils ("absolute" or "eumetallophytes", e. g. Viola calaminaria, V. guestphalica) or in phytogeographically distinct areas on uncontaminated soils ("local metallophytes": e. g. Armeria maritima, Minuartia verna).

\subsubsection{Evolutionary aspects and taxonomic changes}

The origin of metallicolous plant taxa, underlying micro-evolutionary processes and taxonomical problems have been controversial topics of the last decades. The most important new findings on genetic differentiation and the resultant taxonomical consequences are given in six metallicolous taxa.

The Spring sandwort (Leadwort), Minuartia verna (L.) HIERN (Caryophyllaceae), is a perennial, low-growing cushion-forming species (Fig. 2). It is one of the typical pioneer plants of metalliferous sites in the Central European lowlands and on the British Isles (Garcia-Gonzalez \& Clark, 1989). It has a circumpolar distribution and occurs in the arctic regions and in Asian and European high mountains (Meusel et al., 1965), in the Alps particularly on calcareous soils. The subspecies M. verna ssp. hercynica (WILLK.) O. SCHWARZ has recently been confined to metalliferous soils in the lowland and therefore has a disjunctive range. The Harz Mountains, the east Harz foothills in central Germany as well as the Aachen-Stolberg region in western Germany represent the main areas of distribution today (Benkert et al., 1996; Haeupler \& Schönfelder, 1988). Further small-area occurrences are confined to northern Thuringia (Bottendorf Hills), Weserbergland (Blankenrode), the region of Osnabrück (Hasbergen), and eastern Belgium (Liège region). On non-metalliferous sites it is confined to parts of the Franconia Jura mountains (ssp. verna; Haeupler \& Schönfelder, 1988). The occurrence of M. verna on anthropogenic metalliferous sites in the Harz Mountains was first recorded by Thal (1588). This is probably the first recognition of a plant species growing on anthropogenic sites in the scientific literature. Even though the mechanisms of metal-tolerance are not yet completely known, $M$. verna apparently realizes a reduced root uptake and an excreting mechanism of metals through leaf hydathodes (Neumann et al., 1997).

M. verna is confined to open plain sites on raw soils with only a thin cover of fine grained substrate. The dead cushions decompose very slowly and facilitate the initial humus of the raw soils (Schubert, 1953/54). In later successive stages M. verna is replaced due to its low shadow tolerance which disables survival in dense grassland vegetation. 


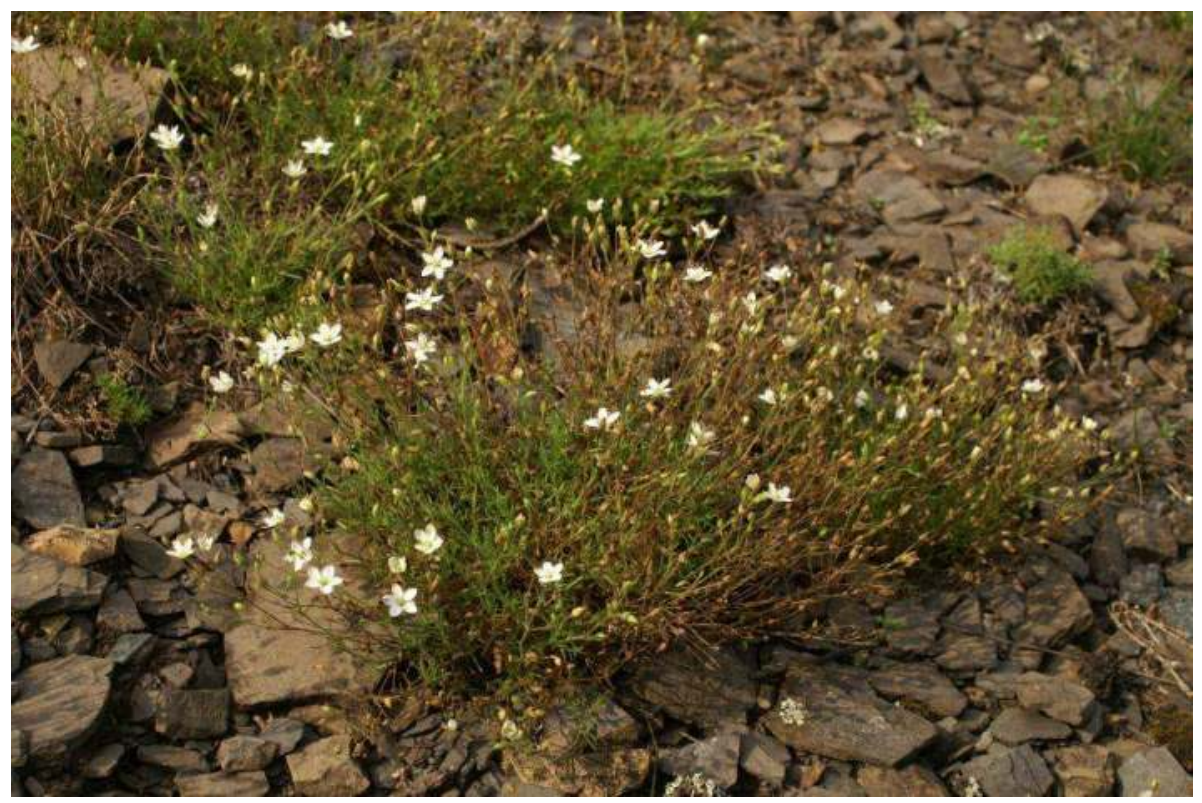

Fig. 2. Minuartia verna, one of the character species of metallicolous vegetation in Central Europe, is critically endangered in some regions due to the loss of habitats (photograph: $\mathrm{H}$. Baumbach).

Minuartia verna is one of the central European character species of metalliferous soil sites that has been considered as glacial relic and therefore paleo-endemics (Schulz, 1912; Schubert, 1954a; Heimans, 1961; Ernst, 1974). Due to the large morphological variation within the Minuartia verna-complex several of the described subspecies and varieties (e. g. Graebner, 1919, Hayek, 1922; Mattfeld, 1922; Halliday, 1964) can only be delineated bio-geographically or edaphically. The necessity of a critical revision of the Minuartia verna-complex has already been postulated by Ernst (1974), nevertheless this revision still is lacking.

Molecular data obtained in the only DNA-study (Baumbach, 2005) undertaken support the paleao-endemism hypothesis of the metallicolous lowland forms of $M$. verna which are clearly separated from the alpine taxon (ssp. gerardii). One hundred and three individuals from eight metallicolous lowland populations and three non-metallicolous alpine populations have been analysed using AFLP (amplified fragment length polymorphism). Five primer combinations have been used to generate 199 polymorphic loci. Genetic variability within Minuartia verna-populations was lower (14\% average heterozygosity; $37 \%$ polymorphic loci) than in metallicolous populations of Silene vulgaris (see below) and Armeria maritima (Baumbach \& Hellwig, 2007). Within non-metallicolous populations, genetic variability was clearly and significantly higher than within metallicolous populations. Geographical and genetic distances were highly positively correlated $(\mathrm{r}=0.81$; $\mathrm{p}<0.001$ ). AMOVA revealed a stronger genetic differentiation of the metallicolous populations than of the non-metallicolous populations. Genetic variation within lowland populations was remarkably lower (52\%) than within the alpine populations (86 \%). At least some ancestral populations obviously preserved at primary metalliferous sites from the 
post-glacial until the beginning of ore mining. Furthermore, high genetic differentiation among the metallicolous lowland groups, the low genetic variability within populations and the comparably high ITS variation indicate a long-term isolated evolution within the different regions. This should be kept in mind when maintaining an aggregation of all metallicolous lowland forms to a widely considered ssp. hercynica in terms of Schwarz (1949) and Schubert (1954a). Results of an ongoing AFLP- and ITS-study (Baumbach, in prep.) including $30 \mathrm{M}$. verna-populations from 12 geographical regions from central Europe will illuminate further aspects.

Another character species of metalliferous soils is the Bladder Campion, Silene vulgaris (MOENCH) GARCKE (Caryophyllaceae). It was reported from nearly all abandoned ore mining sites in Central Europe (compare Ernst, 1974; Pardey, 1999a; Baumbach, 2000; Golde, 2001; and others) where it usually initiates the succession of vascular plant communities, especially on steep slops of spoil-heaps. The morphologically differentiated form growing on mining and smelter heaps was first mentioned by Schulz (1912) who considered it as belonging to the var. angustifolia Garcke. It was formally recognised as var. humilis by Schubert (1954a). The main motivation for the separation from the var. angustifolia was the restriction of the var. humilis to metalliferous heaps. Morphologically it was chiefly characterised by a dwarfed, prostrate growth, smaller and narrower leaves, fewer flowers per shoot, and smaller seeds than the normal variety. However, Schubert (1954a) mentioned the large variation of the morphological features found alone in one heap population. Nevertheless, Rothmaler (1963) elevated the status of the var. humilis to a subspecies humilis. Physiologically plants of the "humilis" type were assumed to show higher metal-tolerance (Schubert, 1954a). In contrast, Bröker (1963) and Gries (1966) demonstrated that morphological features and metal-tolerance are not associated in Silene vulgaris. This result is consistent with a physiological study (Wierzbicka \& Panufnik, 1998) which showed that the humilis-form is mainly a morphological response to water stress and nutrient deficiency often occurring on the exposed and coarse-grained mining dumps, but not due to the metalliferous soil conditions themselves. Several recent and previous papers have illuminated particular physiological aspects of the metal-tolerance (for discussion see Baumbach, 2005). Schat et al. (1993) proposed a general model for the genetic control of copper tolerance in Silene vulgaris. More important, crossing experiments by Schat et al. (1996) have shown that tolerance loci for zinc, copper, and cadmium in plants of an Irish population from a metalliferous site were identical with those in several German populations from metalliferous sites. They argued that the occurrence of common major genes for tolerance among different geographically isolated populations must have resulted from independent parallel evolution in local non-tolerant ancestral populations. Furthermore Schat \& Vooijs (1997) examined the co-segregation of tolerances to $\mathrm{Cu}, \mathrm{Zn}, \mathrm{Ni}$, $\mathrm{Co}$, and $\mathrm{Cd}$ in crosses between distinctly tolerant ecotypes. The results demonstrated a nonpleiotropic genetic control of tolerance to $\mathrm{Cu}, \mathrm{Zn}$, and $\mathrm{Cd}$ while tolerance to $\mathrm{Ni}$ and $\mathrm{Co}$ seems to represent the pleiotropic by-product of the tolerance allele of one particular locus for zinc tolerance. As these studies show, there is no all-embracing metal tolerance, rather a population-specific response to the site-specific soil factors. A study using AFLP (Baumbach, 2005) compared the genetic differentiation of Silene vulgaris-populations from different regions in eastern Belgium and Germany. One hundred forty individuals out of five pairs of populations (one metallicolous and one non-metallicolous in the surroundings each) and four additional single populations have been sampled. One hundred thirty-four 
polymorphic and reproducible loci, generated with three primer combinations, have been used. Detected genetic variability within Silene vulgaris-populations was comparatively high (20\% average heterozygosity, $64 \%$ polymorphic loci). There was no significant difference in parameters of genetic variability between metallicolous and non-metallicolous populations. An analysis of molecular variance (AMOVA) resulted in a comparatively low genetic differentiation of the populations $\left(\Phi_{\mathrm{ST}}=0.25\right)$. Correspondingly, (hypothetical) gene flow between populations is high $\left(\mathrm{N}_{\mathrm{e}} \mathrm{m}=0.74\right)$. Genetic variation within populations (more than $70 \%$ ) exceeds variation among them. AMOVA reveals geographical partition of genetic variance while grouping into metallicolous vs. non-metallicolous populations was not supported by the data. The clear geographical grouping of population pairs (metalliferous and normal soil populations each) supports the hypothesis of polytopic and reiterate colonization events of metalliferous sites by tolerant ecotypes from neighbouring populations on normal soils. In conclusion, a Silene vulgaris taxon "humilis" (subspecies or variety) should be rejected because it is neither characterised by genetic markers, nor by exclusive morphological features or an exclusive metal-tolerance.

One of the most interesting and best studied plant species of metalliferous sites in Central Europe is the Thrift, Armeria maritima (MiLl.) WILlD. s. 1. (Plumbaginaceae), which can also be found in some geographical regions on non-metalliferous soils. The A. maritima complex is highly polymorphic and has been subdivided into eight infraspecific taxa (Pinto da Silva, 1972) that can be easily characterized geographically and ecologically but are difficult to distinguish morphologically. The non-metalliferous soil taxa of Central Europe are ssp. alpina, which is confined to the subalpine belt of the Alps, ssp. maritima (at all Western European coasts), and ssp. elongata (mainly on sandy soils in sub continental Europe and at the Baltic Sea coasts). Within the Central European range of ssp. elongata we find at least four described taxa of A. maritima which are confined to metalliferous soil sites. The status of these metallicolous taxa has been controversial, and has changed several times (Wallroth, 1842; Schulz, 1912; Christiansen, 1931; Schubert, 1954a; Ernst, 1974; Lefebvre, 1985; Wisskirchen \& Haeupler, 1998) because the morphological characters used to discriminate these taxa are not always constant at the level of populations. Local populations may contain plants that can be assigned to distinct infraspecific taxa growing side by side. Studies performed with isozymes (Vekemans \& Lefebvre, 1997; Vekemans et al., 1992) and RAPD markers (Baumbach \& Hellwig, 2003) revealed that the large morphological variation corresponds to large genetic variation occurring within the A. maritima complex and strong differentiation at the population level.

Furthermore, results of an AFLP study (Baumbach \& Hellwig, 2007) give strong evidence that metallicolous populations have been founded from the ancestral non-metallicolous populations repeatedly and independently in different geographical regions. The metallicolous Armeria maritima microendemics "hornburgensis", "bottendorfensis", "eifeliaca", "calaminaria“ should not be given formal rank as varieties or subspecies within A. maritima. Also their treatment as varieties of an A. maritima subspecies halleri sensu latu (Wisskirchen \& Haeupler, 1998) is doubtful because ssp. halleri can not be consistently characterized throughout its geographical range and may be an artefact itself. All investigated metallicolous forms show close relations to Armeria maritima ssp. elongata. If a taxonomical recognition should be considered necessary it is advisable to treat the microendemics as varieties of that subspecies (Baumbach \& Hellwig, 2007). 
Cardaminopsis halleri (L.) HAYEK (Brassicaceae) is a wide-spread pseudo-metallophyte which occurs at metalliferous and non metalliferous sites (meadows, watersides, rocks). The genetic structure of 28 metallicolous and non-metalicolous populations with a total of 625 individuals was studied by Pauwels et al. (2005) using PCR-RFLP on chloroplast DNA (cpDNA). Eleven distinct chlorotypes were found: five were common to non-metallicolous and metallicolous populations, whereas six were only observed in one edaphic type (five in non-metallicolous and one in metallicolous). No difference in chlorotype diversity between edaphic types was detected. Computed on the basis of chlorotype frequencies, the level of population differentiation was high but remained the same when taking into account levels of molecular divergence between chlorotypes. Isolation by distance was largely responsible for population differentiation. As it was the case in Silene vulgaris (Baumbach, 2005) geographically isolated groups of metallicolous populations were more genetically related to their closest non-metallicolous populations than to each other. These results suggest that metallicolous populations have been established separately from distinct non-metallicolous populations without suffering founding events and that the evolution towards increased tolerance observed in the distinct metallicolous population groups occurred independently.

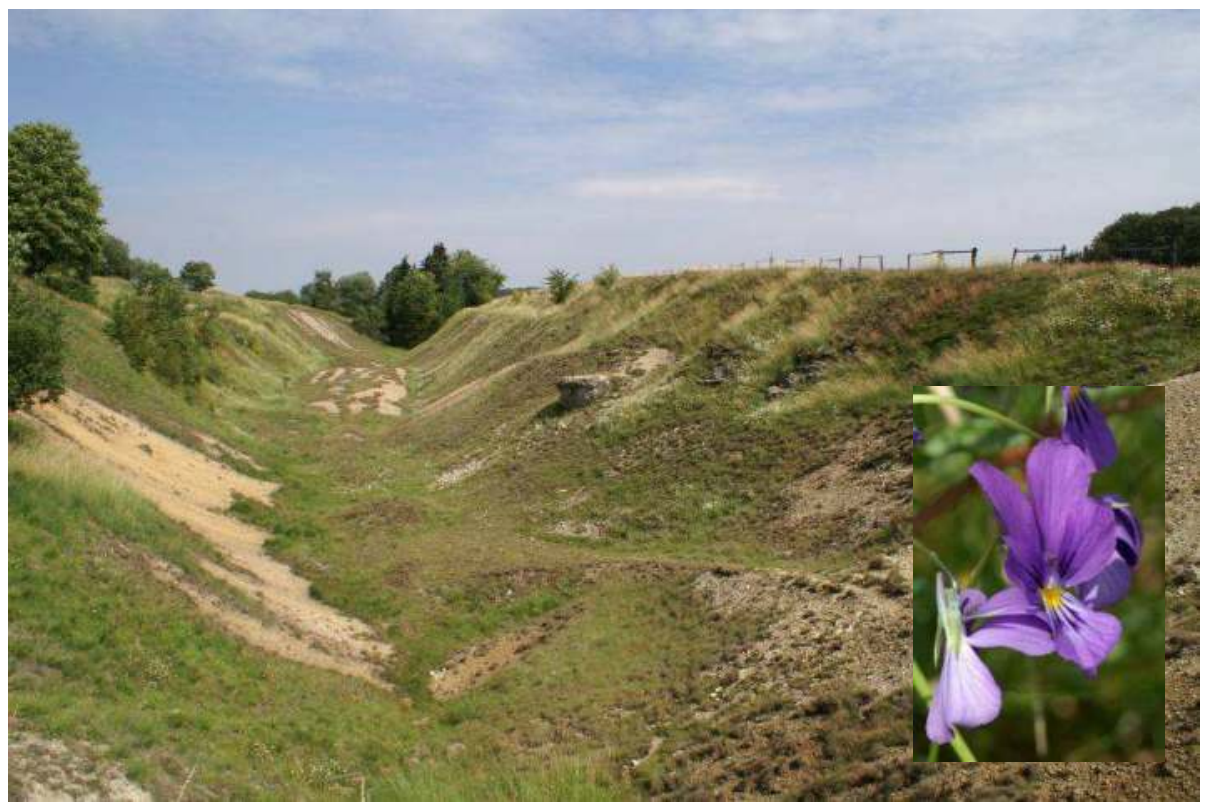

Fig. 3. Old lead-zinc opencast mining near Blankenrode (Germany), type locality of Viola guestphalica (small picture), the Westfalian zinc violet (photograph: H. Baumbach, July 2011).

The Alpine penny-cress, Thlaspi caerulescens J. PRESL et C. PRESL (Brassicaceae), is a perennial, rosette-forming plant with clusters of white to pink flowers. With occurrences on metalliferous and non-metalliferous soils in Central Europe and on the British Isles the plant is a typical pseudo-metallophyte. The metal-ecotype of T. caerulescens was described as subspecies calaminare (LEJ.) BäsSLER. Isozyme-analyses (Koch et al., 1998) have indicated, 
that a taxonomical subdivision of $T$. caerulescens into a taxon of metalliferous soils (ssp. calaminare) and a taxon of non-metalliferous soils is not possible and, furthermore metal tolerance might have evolved twice in populations from different areas.

The Zinc Violet, Viola calaminaria (GING.) LEJ., is the characteristic plant species of calamine sites in the Aachen-Stolberg-Liege region (the three border region of West-Germany, EastBelgium, and South-Netherlands). The blue flowering Westphalian zinc violet, Viola guestphalica is locally endemic, restricted to the former zinc-lead opencast "Bleikuhle" near Blankenrode (Fig. 3). Taxonomy and biogeography of both species were controversially discussed in numerous publications (e. g. Schulz, 1912; Heimans, 1961; Ernst, 1974; Nauenburg, 1986; and others) within the last decades. A recent study (Hildebrandt et al., 2006) has shown close relationship of both taxa and with Viola lutea HuDS. The authors consequently propose the treatment of both taxa as subspecies (ssp. calaminaria (LEJ.) ROTHM. and ssp. westfalica (W. ERNST) J. HeIMANS) of the alpine Mountain pansy, Viola lutea.

\subsection{Vegetation}

\subsubsection{The classical syntaxonomical concept}

The metallicolous vegetation of Central Europe is characterized by plant communities of the order Violetalia calaminariae Br.-Bl. et Tx. 1943 nom inval. Ernst $(1965,1974,1976)$ proposed the sub-division of this order into the following three alliances:

1. Thlaspion calaminariae Ernst 1965: Metallicolous vegetation of Western-central- and Western Europe with only Thlaspi caerulescens as character species of the alliance. It includes the associations of the Violetum calaminariae Schwick. 1931 and the Minuartio-Thlaspietum caerulescens K. Koch 1932. The Violetum calaminariae can be subdivided geographically in eastern and western areas with the blue flowering zinc violet (Viola guestphalica) in the Violetum calaminariae westfalicum at Blankenrode (Germany) its only site in the world, and the yellow flowering Viola lutea subsp. calaminaria in the Violetum calaminariae rhenanicum.

2. Armerion halleri Ernst 1965: Metallicolous vegetation in the more eastern parts of Central Europe with Armeria halleri as exclusive character species of the alliance. The Armerion halleri includes the associations of the Armerietum halleri Libb. 1930, the Armerietum hornburgensis Schub. 1974, the Armerietum bottendorfensis Schub. 1953, and the Holco-Cardaminopsietum halleri Hülb. 1980 (Schubert et al., 2001).

3. Galio anisophylli-Minuartion vernae Ernst 1964: Metallicolous vegetation in the Alps, characterized by widely distributed alpine species (Galium anisophyllum, Poa alpina, Euphrasia salisburgensis, Dianthus sylvestris) and in the Italian and Austrian Alps with Thlaspi rotundifolium ssp. cepaeifolium and the endemic Viola dubyana (Baker et al., 2010).

\subsubsection{Proposed syntaxonomical changes}

Despite the fact that this system was accepted for almost four decades, recent publications proposed some new approaches due to new records and a re-visitation of the existing vegetation data. Additionally, some of the taxa whose taxonomical position became uncertain are character species of associations, alliances, order or class (Ernst, 1974; Schubert et al., 2001). This also results in a need for new discussion on the exceptional syntaxonomical position of the calaminarian grasslands. 
Baumbach \& Schubert (2008) proposed to discuss an assignment of the metallicolous vegetation in a new alliance Minuartion vernae characterized by Minuartia verna ssp. hercynica. This alliance should be grouped in the vicinity of the Armerion elongatae Krausch 1961 within the order Festuco-Sedetalia acris R. Tx. 1951 and the class KoelerioCorynephoretea Klika in Klika et Novak 1941.

Further vegetation studies are necessary to illustrate these questions and also the autonomy of the several metallicolous plant associations. Calaminarian grasslands have a specific species composition which is characterized by abundant metal-tolerant taxa, and a lack of non-tolerant grassland species. Their physiognomic structure is shaped by dwarfism and little vegetation cover which allows the growth of a rich flora of mosses and lichens. Naturally, in transition zones between metal-rich and metal-free soils there may occur plant stands that legitimate the assignment to sub-associations of dry grassland communities. A complete negation of discrete communities of metallicolous vegetation was, however, opposed by Baumbach \& Schubert (2008).

This is in contrast to Becker et al. (2007) who rejected the Armerietum bottendorfensis. They recognized four communities, in which the metallophytes Armeria maritima (ssp. halleri) and Minuartia verna ssp. hercynica occur in high frequency and classified them as special subassociations (Armerietosum halleri) of four dry grassland associations (Teucrio-Festucetum, Thymo-Festucetum, Filipendulo-Helictotrichetum, Adonido-Brachypodietum).

In the conclusion of a comprehensive study of the metallicolous vegetation of the Western Harz Mountains Dierschke \& Becker (2008) recommended the maintenance of an association Armerietum halleri. A synoptic table with inclusion of relevés from the literature in Germany supports the concept of a narrow class Violetea calaminariae with communities poor in species. For the remaining single alliance they propose the name Armerion halleri Ernst 1965 as nomen conservandum.

The alliance of the Galio anisophylli-Minuartion vernae is not acceptable in the eastern Alps by the Austrian authors (see Punz, 1991, 1994). Based on new vegetation records and tables, Punz \& Mucina (1997) assigned the metallicolous vegetation associations of the Eastern Alps chiefly to the Thlaspietea rotundifoliae (Englisch et al., 1993) and a small part to the Asplenietea trichomanis (Mucina, 1993).

\section{Current situation of metalliferous sites in Central Europe}

\subsection{The situation in the east Harz foothills - a case study in Central Germany}

\subsubsection{Introduction}

The current situation of metalliferous soil sites will be exemplified here by the eastern und south-eastern Harz foothills region (Saxony-Anhalt, Central Germany). For centuries copper-shale mining was active in the Mansfeld (1200-1969) and the Sangerhausen (13821990) mining districts.

The metallicolous vegetation of the copper-shale spoil heaps was intensely studied by Schubert (1953/54). Most of these heaps are not only characterized by calaminarian grasslands in different successive stages but also by raw soils, xerothermous vegetation and shrubberies, which occur tessellate and often in very small areas. Therefore, and due to their 
isolated location within intensive used fields these spoil heaps have a high value for the biodiversity of the landscape.

\subsubsection{Metallicolous vegetation}

The typical calaminarian grassland of the copper-shale spoil heaps is the Armerietum halleri Libb. 1930. As the Armerietum hornburgensis and the Armerietum bottendorfensis it belongs to the alliance of the Armerion halleri Ernst 1965. When compared with the alliance of the western distributed Thlaspion calaminariae Ernst 1965 it is floristically depleted due to the absence of Viola calaminaria and Thlaspi caerulescens. However, it is characterized by a greater number of xerothermous grassland species (compare Schubert, 1953/54; Ernst, 1974; Pardey, 1999a; Dierschke \& Becker, 2008). Cardaminopsis halleri is another typical species of metallicolous vegetation of the Harz Mountains and Western Germany which does not occur in the region.

The character species of the association Armerietum halleri, Armeria maritima (subsp. halleri), and the character species of the class Violetea calaminariae, Minuartia verna (ssp. hercynica) and Silene vulgaris (var. humilis), occur in high frequency (consistency class V). Frequent species are furthermore Festuca ovina agg. and Agrostis capillaris (consistency class IV) as well as Achillea millefolium, Asperula cynanchica, Carlina vulgaris, Campanula rotundifolia, Cirsium acaule, Dianthus carthusianorum, Euphorbia cyparissias, Euphrasia officinalis agg., Galium verum, Hieracium pilosella, Koeleria macrantha, Pimpinella saxifraga, Potentilla heptaphylla, Potentilla neumanniana, Scabiosa ochroleuca, and Thymus praecox (all consistency class III; Schubert, 2001). Characteristic mosses and lichens of the association are Ceratodon purpureus, Bryum caespiticium, Cladonia alcicornis, Cladonia chlorophaea, and Peltigera rufescens (all consistency class III). Other typical lichen species occurring at the spoil heaps are Acarospora bullata, A. sinopica, A. smaragdula, Lecanora stenotropa, L. subaurea, Lecidea inops, Rhizocarpon oederi, and Stereocaulon nanodes (Huneck, 2006). The successive stages of the Armerietum halleri at the copper shale spoil heaps (Minuartia-, Silene-, Euphrasia-, Cladonia-, Armeria-, Festuca- and Brachypodium-stage) have been described by Schubert (1953/54) In the eastern parts of the Mansfeld mining region Minuartia verna is replaced by Alyssum montanum which obviously fulfils the same ecological niche (Gerth et al., 2011).

\subsubsection{Secondary sites}

The most extensive occurrences of metallicolous vegetation can be found on the small mining spoil-heaps which arose between 1200 and 1815. The real number of spoil heaps located in the open landscape was controversially discussed in the last decades. In a recent project we mapped about 1500 small spoil heaps and estimated the vegetation cover by Colour-Infrared (CIR) aerial photographs analysis (of 2005) and field surveys of randomly selected heaps. Till now we mapped the floristic inventory of 650 spoil-heaps in the field. For the inventory we distinguished between (I) small spoil heaps, which originated between the $13^{\text {th }}$ century and 1815 (Fig. 4), and (II) large spoil heaps which originated between 1815 and the end of mining. In contrast to the small spoil heaps the date of origin for the large spoil heaps is exactly known from the mining files. 


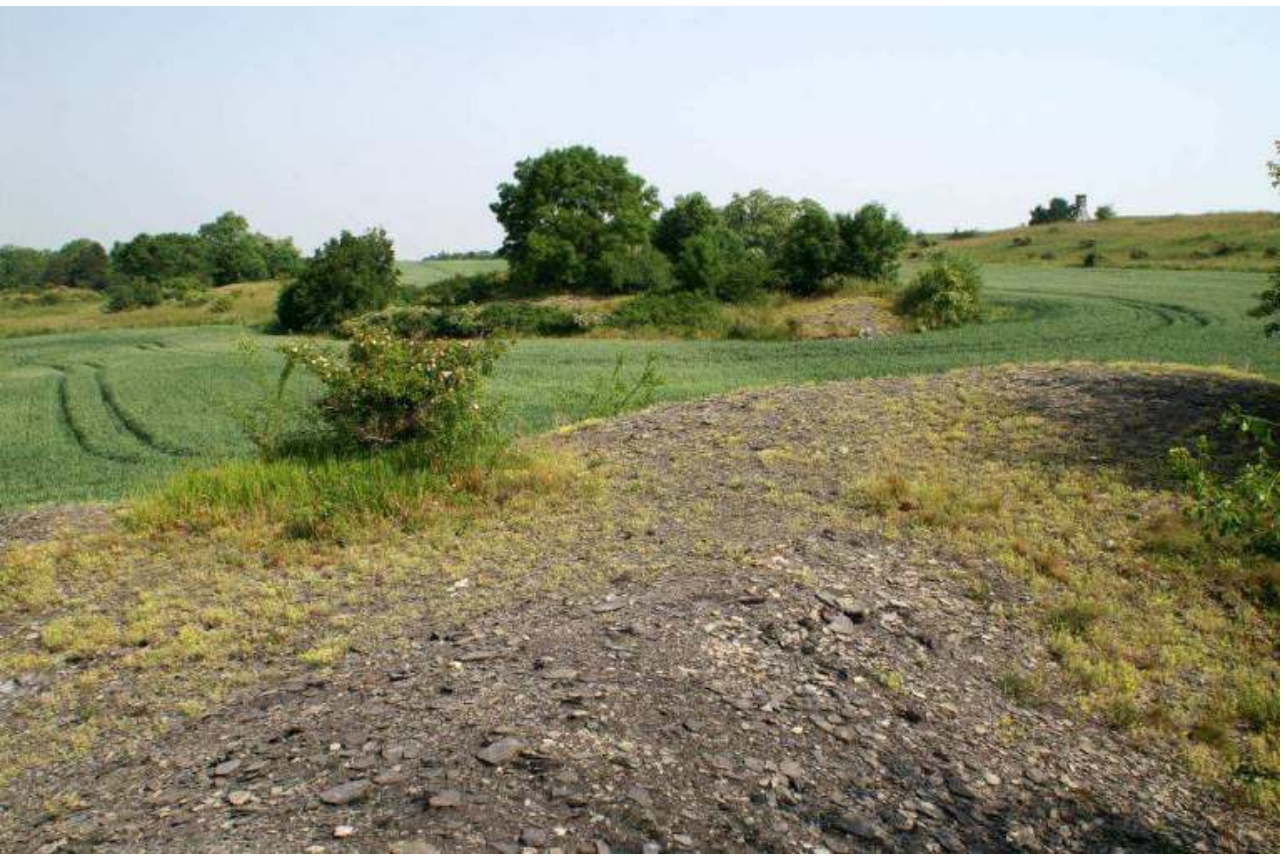

Fig. 4. Spoil heaps of the medieval copper shale mining as secondary metalliferous sites in Central Germany (Dobis, photograph: H. Baumbach, May 2008).

The post-mining landscape consists (state March 2011): in the Mansfeld mining district of 1028 small and 56 large spoil heaps (of which 8 and 12 are slag heaps, respectively), and in the Sangerhausen mining district of 416 small and 9 large spoil heaps (of which 3 and 1 are slag heaps, respectively). Thereby it has to be considered that $60-70 \%$ of the small spoil heaps in the Mansfeld mining district were already destroyed by land burial between 1850 and 1910 (Oertel, 2002). Due to the large amount of metalliferous sites originating in the former copper-mining activities the federal state of Saxony-Anhalt has a particular responsibility towards the preservation of the habitat type 6130. Therefore, three Natura 2000 sites with the habitat type 6130 as the main conservation objective, located in the postmining landscape of the old mines, have been designated (Tab. 3). The total size of these sites is about 687 ha. From this area 137 hectares (19.9\%) are copper-shale spoil heaps with only 21.8 hectares $(3.2 \%)$ of calaminarian grassland. Unfortunately, a comprehensive conservation strategy for these sites is not available to date.

At numerous small spoil heaps the ongoing succession lead to an extensive displacement of the calaminarian grasslands by shrubberies. A total disappearance of the metallicolous vegetation has to be expected on most of the spoil heaps over the long term. The assumption, that metalliferous sites are naturally free of woods (Schubert, 1953/54; Ernst 1974) applies only in early successive stages. In the Sangerhausen mining district more than $75 \%$ of the small spoil heaps are scrubby to more than $80 \%$ (Tab. 2). Only $4 \%$ can still considered as open (scrub encroachment $<10 \%$ ). 


\begin{tabular}{|l|l|l|l|}
\hline $\begin{array}{l}\text { Number of mapped } \\
\text { spoil heaps (N=561) }\end{array}$ & Percentage & $\begin{array}{l}\text { Occurrence of the } \\
\text { character species }\end{array}$ & $\begin{array}{l}\text { Formation of calaminarian } \\
\text { grasslands }\end{array}$ \\
\hline 222 & $40 \%$ & three & at least partial optimal \\
\hline 112 & $20 \%$ & two & fragmentary \\
\hline 98 & $17 \%$ & one & only initial stages \\
\hline
\end{tabular}

Table 1. Occurrence of the character species (Minuartia verna, Silene vulgaris, and Armeria maritima) and formation of calaminarian grasslands (Armerietum halleri) at copper shale spoil heaps $(\mathrm{N}=561)$ in the Mansfeld region.

In comparison, the situation in the Mansfeld mining district is much better. Only one third of the small spoil heaps is scrubby to more than $80 \%$, and $26 \%$ of the spoil heaps can be considered open (scrub encroachment $<10 \%$ ). At least initial stages or fragmentarily developed calaminarian grasslands can be found on $37 \%$ of the mapped spoil heaps. On 40 $\%$ of the spoil heaps optimally developed calaminarian grasslands with all three character species occur at least partially (Tab. 1). When considering only the Natura 2000-sites the situation of scrub encroachment is slightly better (Tab. 3): $18 \%$ of the small spoil heaps are scrubby to more than $80 \%$, and $31 \%$ can considered as open (scrub encroachment $<10 \%$ ). Nevertheless, calaminarian grasslands occur at only $62 \%$ of the spoil heaps.

\begin{tabular}{llllllllll}
\hline & N & \multicolumn{8}{c}{ Percentage of spoil heaps per scrub encroachment class } \\
\hline Mining district & & $\mathbf{0}$ & $\mathbf{1}$ & $\mathbf{2}$ & $\mathbf{3}$ & $\mathbf{4}$ & $\mathbf{5}$ & $\mathbf{6}$ & $\mathbf{7}$ \\
\hline Mansfeld & 996 & 7.9 & 17.8 & 10.9 & 14.2 & 8.0 & 13.0 & 14.2 & 14.1 \\
Sangerhausen & 408 & 2.5 & 1.7 & 1.2 & 3.9 & 4.7 & 8.8 & 29.2 & 48.0 \\
\cline { 2 - 11 } Total & 1404 & 6.3 & 13.0 & 8.0 & 11.1 & 7.0 & 11.7 & 18.4 & 23.8 \\
\hline
\end{tabular}

Table 2. Scrub encroachment of the spoil heaps in the Mansfeld and Sangerhausen copper shale mining districts. $\mathrm{N}$ : total number of spoil heaps. Scrub encroachment classes: 0: $0 \%, 1$ : $1<10 \%$, 2: 11-20 \%, 3: 21-40 \%, 4: 41-60 \%, 5: 61-80 \%, 6: 81-100 \%, 7: $100 \%$.

Assuming, that the large number of sites alone is adequate for the protection of metallicolous vegetation, the need for any restoration measurements was neglected until recently (Baumbach \& Schubert, 2008). A rethinking of this position took place with the results of an inventory (Baumbach, 2008) that showed the high degree of scrub encroachment on many spoil heaps. Consequently, a priority list with 50 spoil-heaps which primarily need biotope management was compiled by the nature conservation authority in 2009. The first of the proposed measures (removal of shrubs, cutting of trees and removal of top soil humus layer) were realized in autumn 2010 and spring 2011. As these actions were recent, an evaluation of the project's success is still pending.

Despite natural succession the current main reasons of the decline of metalliferous habitats are conflicts between intensive agriculture (input of fertilizers and herbicides from the surrounding fields, plough up heap margins), removal of material for road construction, motocross and quad activities by juveniles (which is in particular critically for the slow growing cryptogams), and deposition of domestic waste and rubble (especially in the surroundings of villages). Furthermore, the construction of new roads and the extension of housing development led to the loss of numerous spoil heaps within the last 20 years. A serious problem may arise from increasing metal prices which make the metalliferous spoil heaps attractive for extracting their remnant metal contents. 


\begin{tabular}{|c|c|c|c|c|c|c|c|c|c|c|c|c|}
\hline \multirow[t]{2}{*}{$\begin{array}{l}\text { Site } \\
\text { Number }\end{array}$} & \multirow[t]{2}{*}{6130 -area [ha] } & \multirow[t]{2}{*}{$\mathbf{N}_{\text {total }}$} & \multicolumn{2}{|l|}{6130} & \multicolumn{8}{|c|}{$\begin{array}{l}\text { Percentage of spoil heaps per } \\
\text { scrub encroachment class }\end{array}$} \\
\hline & & & $\mathbf{N}$ & $\%$ & 0 & 1 & 2 & 3 & 4 & 5 & 6 & 7 \\
\hline DE4335-301 & 12,37 & 273 & 170 & 62 & 18 & 25 & 11 & 15 & 8 & 12 & 7 & 4 \\
\hline DE4434-302 & 4,10 & 84 & 67 & 80 & 6 & 26 & 17 & 23 & 10 & 11 & 4 & 5 \\
\hline DE4434-303 & 5,34 & 104 & 49 & 47 & 0 & 2 & 5 & 12 & 13 & 25 & 30 & 13 \\
\hline total & 21,81 & 461 & 286 & 62 & 11 & 20 & 11 & 15 & 10 & 15 & 12 & 6 \\
\hline
\end{tabular}

Table 3. Natura 2000 sites in the Mansfeld region where the spoil heaps with calaminarian grasslands (habitat type 6130) are the main objective. 6130-area: total size of the calaminarian grassland in hectares, $\mathrm{N}_{\text {total }}$ : total number of spoil heaps in the Natura 2000 site, Number $(\mathrm{N})$ and percentage (\%) of spoil heaps with calaminarian grasslands. For definition of scrub encroachment classes see table 2 .

The large spoil heaps that arose between 1815 and 1990 dominate the landscape scenery. Nevertheless, they are mainly endangered by production of gravel for road-building. Currently seven large spoil heaps with an original volume of 21 million $\mathrm{m}^{3}$ and a ground area of 103 hectares are under mining retreat for gravel production. Many other spoil heap surfaces were used as dumping ground for sewage sludge, domestic and industrial waste (e. g. fly ash, filter dust). With regard to metallicolous vegetation this was seen uncritically in the past because two of the character species, Minuartia verna and Armeria maritima, are either totally absent at the large spoil heaps or have only very small-scale occurrences. Other groups of organisms were more or less neglected. A study by Huneck (2006) revealed a high diversity of lichens (96 recorded species) which are mainly confined to open spoil-heap surfaces. This very fact would be reason enough for a strong conservation of the remnant spoil heaps. Moreover, to date there is no comprehensive knowledge on the importance of the spoil heaps for biodiversity of fauna and fungi.

\subsubsection{Primary sites}

Within the Mansfeld mining district there are at least three primary metalliferous soil sites which have not been disturbed by mining activities in the past. One of them is the locus classicus of Armeria maritima ssp. hornburgensis at the Galgenberg Hill near the village of Hornburg. This Natura 2000 site (DE 4535-303) has a total area of 2 hectares from which only $170 \mathrm{~m}^{2}$ are metallicolous vegetation. Interestingly Minuartia verna does not occur there. At the beginning of the 1960s numerous Black pines (Pinus nigra) were planted at the hill. Until the end of the 1990s they caused a decline of the site to $10 \%$ of its former size. The population size of Armeria m. ssp. hornburgensis decreased from still 200 individuals in 1965 to only 100 in 1999 (Baumbach \& Volkmann, 2002). In 200131 Black pines were completely removed. This and a partial mowing with subsequent removal of the biomass led to a stabilization and extension of the population to 383 in 2006 (Baumbach \& Volkmann, 2006). Nevertheless, the situation is furthermore critical due to the tiny area of the site.

Another recently discovered site is located near Mansfeld at the castle mountain. Only a few square metres Minuartia verna and Armeria maritima grow on solid Rotliegend substrate without a fine soil layer. A detailed study of the vegetation and an analysis of the substrate are still pending. 


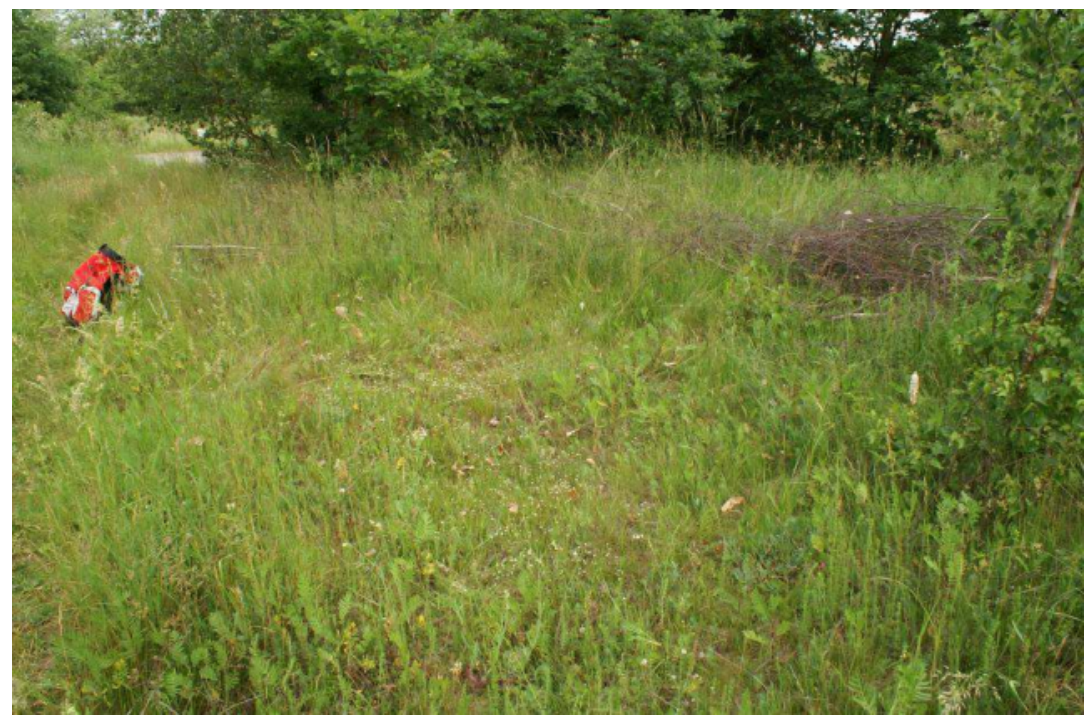

Fig. 5. Primary metalliferous site near Blankenheim (Saxony-Anhalt, Central Germany). This small site is critically endangered by shading and litter input from the surrounding grassland (photograph: H. Baumbach, June 2006).

A third site, located in the east of the village of Blankenheim, was accidentally discovered in 1999 (Fig. 5). The site is subdivided into 5 subareas with a size of only some square metres each (Tab. 4). The soil layer is only $25 \mathrm{~cm}$ thick and covers an outcrop of metalliferous sandore. Obviously this site was never disturbed by mining activities because sand-ores were not suitable for smelting. Furthermore, this site is located outside the former active mining area. To date this very small site has no conservational state. It is critically endangered by shading and litter input from the surrounding grassland (Arrhenatheretum) and by accidental destruction. The genotypes of the Minuartia verna-population growing at this site have both characters of the alpine populations and characters of the spoil heap populations (Baumbach, 2005). This indicates that the M. verna-population has survived on this site since the last ice age and is therefore a real paleo-endemic.

\subsubsection{Tertiary sites}

The sole tertiary metalliferous soil site of the region is located at the former vineyard in Hettstedt-Burgörner (Baumbach et al., 2007). It originated from decades of emissions from downwind located copper, lead, and zinc smelter Kupferkammerhütte (1493-1990). The first damages to the vegetation resulting from smelter emissions were reported by Freytag (1870). The current vegetation at the vineyard is not only due to metal contamination but also to sulphur dioxide emissions from the former Kupferkammerhütte smelter located in the north and northwest, the smelter Kupfer-Silber-Hütte located in the southwest, and the rolling mill located in the west. The total area influenced by the emissions of the smelters covers approximately 11 hectares. On the most impacted western slope of the vineyard the top soil is covered by a layer of dust up to $25 \mathrm{~cm}$ with high amounts of metals and semi-metals. 
Metallophytes and Metallicolous Vegetation:

Evolutionary Aspects, Taxonomic Changes and Conservational Status in Central Europe

\begin{tabular}{|c|c|c|c|c|c|}
\hline Subarea & 1 & 2 & 3 & 4 & 5 \\
\hline Size $\left(\mathrm{m}^{2}\right)$ & 6 & 1 & 3 & 2 & 9 \\
\hline Exposition & $S$ & $S$ & $S$ & $S$ & $S$ \\
\hline Inclination $\left(^{\circ}\right)$ & 5 & 8 & 8 & 8 & 10 \\
\hline Total vegetation cover (\%) & 98 & 95 & 98 & 100 & 100 \\
\hline Cover of mosses and lichens (\%) & 8 & 2 & 2 & 2 & 5 \\
\hline Number of species (phanerogams) & 27 & 8 & 8 & 9 & 15 \\
\hline Armeria maritima & + & & 1 & & 1 \\
\hline Minuartia verna & 3 & + & 1 & 1 & $\mathrm{r}$ \\
\hline Silene vulgaris & + & 1 & & & \\
\hline Festuca rupicola & 3 & 3 & 3 & 4 & 4 \\
\hline Galium verum & + & + & 1 & 1 & + \\
\hline Euphorbia cyparissias & + & & + & + & + \\
\hline Hieracium pilosella & & 1 & + & + & $\mathrm{r}$ \\
\hline Rumex acetosa & 1 & & & $\mathrm{r}$ & + \\
\hline Potentilla tabernaemontani & + & & & & + \\
\hline Centaurea stoebe & $\mathrm{r}$ & & & & + \\
\hline Eryngium campestre & & & & & $\mathrm{r}$ \\
\hline Achillea pannonica & + & & & + & $\mathrm{r}$ \\
\hline Dianthus carthusianorum & $\mathrm{r}$ & & & & $\mathrm{r}$ \\
\hline Plantago lanceolata & $\mathrm{r}$ & & $\mathrm{r}$ & & \\
\hline Festuca pratensis & & + & & & + \\
\hline Poa pratensis & & & & & + \\
\hline Leontodon autumnalis & & & & & + \\
\hline Trifolium campestre & + & $\mathrm{r}$ & & & \\
\hline Tanacetum vulgare & 1 & $\mathrm{r}$ & & & \\
\hline Plantago intermedia & $\mathrm{r}$ & & & & \\
\hline Lotus corniculatus & + & & & & \\
\hline Hieracium lachenalii & $\mathrm{r}$ & & & & \\
\hline Arrhenatherum elatius & 1 & & & & \\
\hline Dactylis glomerata & 1 & & & & \\
\hline Tragopogon pratensis & + & & & & \\
\hline Veronica chamaedrys & + & & & & \\
\hline Brachypodium pinnatum & 1 & & & & \\
\hline Agrostis stolonifera & & & & + & \\
\hline Lathyrus pratensis & & & + & & \\
\hline Falcaria vulgaris & & & & $\mathrm{r}$ & \\
\hline Daucus carota & + & & & & \\
\hline Artemisia vulgaris & $\mathrm{r}$ & & & & \\
\hline Betula pendula & 1 & & & & \\
\hline Rosa inodora & 1 & & & & \\
\hline Rosa elliptica & 2 & & & & \\
\hline
\end{tabular}

Table 4. Vegetation relevés of the primary metalliferous site near Blankenheim (SaxonyAnhalt), Braun-Blanquet scale, inventory date: $15^{\text {th }}$ of June, 2006. 
Therefore it is characterised by extended metallicolous vegetation ( $3.5 \mathrm{ha}$ ), which is meagre in plant species and dominated by the characteristic species of the Armerietum halleri, Armeria maritima, Minuartia verna, and Silene vulgaris (all consistency class V). Furthermore, frequently occur Agrostis stolonifera, Rumex acetosa and Festuca rupicola (V), and with low frequency Brachypodium pinnatum, Sanguisorba minor, Plantago lanceolata, Pimpinella saxifraga, Ranunculus bulbosus, Daucus carota, Cerastium holosteoides, Artemisia vulgare, Erigeron acre, Convolvulus arvensis, Tussilago farfara, Lonicera xylosteum, Tilia cordata, Ulmus minor, Betula pendula, Acer pseudoplatanus, and Acer campestre (all consistency class I).

Some locally extreme concentrations of metals were found in the soil surface horizon at the middle slope (Tab. 5). Afforestation of the site performed in 1993 was unsuccessful. Nevertheless, parts of the upper slope and the plateau region (7.7 ha) of the vineyard are covered by extended birch pioneer forests as a result of natural succession. Due to shade the metallicolous vegetation disappeared there and was not replaced by other herbaceous vegetation. Therefore the top soil is strongly affected by erosion and solifluction.

\begin{tabular}{lllllllllll}
\hline SP & $\mathbf{N}$ & $\mathbf{E}$ & $\mathbf{P b}$ & $\mathbf{Z n}$ & $\mathbf{C u}$ & As & Mn & Cd & Co & Ni \\
\hline 1 & 5721923 & ${ }^{44} 66248$ & 8294 & 7482 & 3121 & 471 & 441 & 116 & 15.4 & 40.4 \\
2 & 5721904 & ${ }^{44} 66277$ & 16019 & 14192 & 3601 & 1097 & 574 & 293 & 14.8 & 42.1 \\
3 & 5721897 & ${ }^{44} 66286$ & 9664 & 2537 & 992 & 506 & 155 & 58 & 9.6 & 19.6 \\
4 & 5721876 & ${ }^{44} 66332$ & 170 & 159 & 146 & 21 & 36 & 2 & 1.6 & 8.1 \\
\hline
\end{tabular}

Table 5. Metal mass-concentrations [mg/ $\mathrm{kg}$ dry weight] in the upper soil layer of four sampling points (SP) on the vineyard. Method: nitric acid pulping (DEV-A32), ICP/MS. Location of the PP: lower (1), middle (2), and upper (3) middle-slope, upper-slope (4). N: northing; E: easting in Gauss-Krüger coordinates $\left(3^{\circ}\right.$ wide strips, Bessel ellipsoid, Potsdam datum, Rauenberg central point).

The vineyard will long be characterized by high soil-metal concentrations. With respect to the size of the polluted area a soil exchange or a cover with arable substrates is not possible. Regarding the results of the sequential extraction, the soil and the climate conditions in the region, the danger of medium-term mobilisation of metals via water or air seems to be low. The vineyard is the largest known site with metalliferous vegetation in Central Germany. Therefore, Baumbach et al. (2007) proposed to protect it to allow long-term observations of the regeneration processes in biocenoses at metal-contaminated sites.

\subsection{The situation in other regions}

\subsubsection{Germany}

In total, Germany has 36 Natura 2000 sites where the habitat type 6130 occurs. In 21 of them this habitat type is the main reason for site protection. The protection by the European Habitats Directive and the establishment of the Natura 2000 network lead to conservation efforts in several regions.

The only metalliferous site in Thuringia is located at Bottendorf Hill in the lower Unstrut valley (Schubert, 1954b; Becker et al., 2007). It is the type-locality of Armeria bottendorfensis and probably the largest primary site in Germany. The primary site on the southern slope and some small copper-shale spoil heaps on top of the hill are part of the Natura 2000 site 
(DE4634-303) with a total size of 133 ha. The area is characterized by continental drygrasslands which are in a very good state of preservation due to sheep pasturing.

The metallicolous vegetation of the West-Harz Mountains (Lower Saxony) was recently revisited by Dierschke \& Becker (2008). Although their focus is on subdivision, environmental conditions and a syntaxonomical classification of the Armerietum halleri they also highlight conservational aspects. A comparison of the current number of metalliferous sites with a 1928 Bode list shows a large decline of sites due to human destruction and natural succession. The reasons for declining of (most small area) metalliferous sites and their vegetation are mainly: destruction by building development, flooding by dams, coverage, removal of slag for re-smelting or for road construction, afforestation, use as storage areas for timber or rock waste, motocross activities, trespass and camping, disturbances by mineral collectors (in particular critical for cryptogams), shading and input of litter by surrounding trees (Dierschke \& Becker, 2008). There are no (at least no published) experiences with management and restoration of metalliferous soil sites in the Harz Mountains. Remarkably, the largest stands of the Armerietum cladonietosum in the Westharz Mountains can be found in a fenced, undisturbed area in the Oker River valley (Dierschke \& Becker, 2008).

More than ten years ago, North Rhine-Westphalia was the first federal state with its own conservation strategy for metalliferous soil sites (Pardey, 1999b). Fortunately, this conservation strategy is not restricted to metallicolous flora and vegetation but also encompasses the fauna of these sites and plans for habitat connectivity in several core areas. To date there are 15 Natura-2000 sites in North Rhine-Westphalia where the habitat type 6130 occurs. In 11 of them it is the main objective for site protection.

First experiments with the restoration of metalliferous sites were made at the end of the 1990s in the Stolberg region. Preliminary results (2003) and a final evaluation (2008) were published by Raskin. Test sites were metalliferous sites with dominating Pine stands and only insular remnants of metallicolous vegetation. Primarily all trees and shrubs were felled and the remnant timber was burned on site in the winter. The next measure was the removal of top soil in strips using muzzle loaders. All organic material (vegetation, humus, litter) was removed from the restoration sites. In the first year six of the seven character species of the calaminarian grasslands colonized on the new raw soil sites. This pioneer vegetation was dominated by Silene vulgaris with scattered occurrence of Minuartia verna. Only after the $5^{\text {th }}$ year did appear also Armeria maritima.

Although the Erzgebirge Mountains (Saxony) were one of the most important ore mining areas in Europe there is meagre knowledge of metallicolous vegetation. Consequentially the first paper on this topic was entitled "Metallicolous vegetation - a so far overlooked habitat type in Saxony" (Golde, 2001). The sites with metallicolous vegetation are fragmented and restricted to the Freiberg region. At these metalliferous sites Minuartia verna is totally absent and Armeria maritima has only a very small occurrence (Golde, 2001). If metallicolous ecotypes of Silene vulgaris und Thlaspi caerulesens loose their taxonomical rank the definition of the habitat type 6130 is no longer possible by characteristic angiosperm taxa but only by metallicolous cryptogam communities (mainly the Acorosporetum sinopicae). Two Natura 2000 sites where the habitat type 6130 occurs have been designated. In one of them it is the main objective for conservation (DE4945-303). 


\subsubsection{Belgium, Netherlands, and Poland}

In eastern Belgium most of the 35 metalliferous sites are located in the former mining district of the Vielle Montaigne (Plombieres, Kelmis) close to the German mining district of Aachen-Stolberg and the Liege region (Graitson et al., 2003). In total 76 hectares of the habitat type 6130 are located in Natura 2000 sites.

The only metalliferous site of the Netherlands is that of the tertiary type. It is located in the Geul River floodplains near Epen and has an area of about 0.5 ha. Van der Ent (2007) estimates that in 1925 more than $10 \mathrm{~km}$ of the flood plains were dominated by metallicolous vegetation (see also Heimans, 1936). Till now over $99 \%$ has diminished due to a decreased zinc load and increased eutrophication. In 2007/08 first restoration experiments in the field (bulldozing and small scale topsoil removal) were performed.

In Poland metallicolous vegetation of the Armerietum halleri is developed at several spoil heaps in the Olkusz region (Upper Silesia). Two of these sites with a size of 7.4 and 4.9 hectares are Natura 2000 sites (PLH120091, PLH120092). Unfortunately, there is no more (published) information available.

\section{Conclusion}

The review of new findings outlined in the first part of this paper shows the necessity for a taxonomic re-evaluation of several taxa. So far some of them have been used exclusively for the definition of the conservational value of metalliferous sites by the official nature conservation praxis. In consequence, such a re-evaluation may cause considerable formal problems as the Saxon example shows. One danger of taxonomic changes is the argumentation that with a loss of a certain taxonomic rank of the character species also the conservational value of the metalliferous sites becomes obsolete. Therefore I would like to underline that metalliferous sites and their vegetation deserve protection independent from the taxonomic rank of their character species or the syntaxonomy of their plant communities.

It is beyond a doubt that the particular abiotic factors (metal content, drought, nutrient deficiency) and the isolated geographic occurrence of metalliferous sites facilitate the evolution of special adapted and genetically differentiated plant populations. This genetic differentiation is an ongoing process that can lead to the evolution of neo-endemic species. We are still at the beginning of Silene vulgaris, advanced in Armeria maritima (centuries to millennia), and very advanced in Minuartia verna (since the end of the last ice age). Despite any conventional taxonomical rank these taxa deserve protection due to their unique gene pool and their evolutionary potential. Furthermore, they represent a genetic reservoir which could have prospective importance for the colonization and remediation of polluted anthropogenic sites (Whiting et al., 2004).

Apart from flowering plants which have for a long time been in scientific focus, adapted and genetically differentiated populations have to also be expected in lichens, fungi, bacteria and the soil fauna. Knowledge on biodiversity of metallicolous biocenoses is still insufficient and needs further scientific work. Based on this a comprehensive ecological and conservation biological evaluation should be carried out. Furthermore I propose to protect metalliferous sites as "evolutionary playgrounds", independent of the actual occurrence of rare or legally 
protected species. This is of course only feasible if there is no danger for human health and the natural environment through causes by the respective sites.

Whereas most of the secondary sites have been well investigated, the importance of primary metalliferous soil sites (for example as source of the palaeo-endemic metallophyte taxa) was underestimated for a long time and the knowledge of these sites is still poor. To date we only know of a few undisturbed, small sized metal outcrops with metallicolous vegetation in the Central European lowland. Most of them are critically endangered. The knowledge of these sites and their management requires further research.

To provide an efficient long-term protection of metalliferous sites and their biocenoses in Central Europe conservation strategies should be implemented both at a regional and a supra-regional scale. A supraregional conservation strategy should develop with participation of all Central European Countries (Germany, Belgium, Poland, Netherlands) and their federal states where metalliferous soil sites occur, respectively. Regional conservation strategies (e. g. Germany: Saxony-Anhalt, Lower Saxony, Thuringia) should consider the specific characteristics of the several regions. Model should be the "Conservation strategy for calaminarian sites in North Rhine-Westphalia" (Pardey , 1999b).

These conservation strategies should account the following main aspects: protection of the remnant metalliferous sites with special regard to the primary ones, population biology of the character species (minimum area, minimum viable population, maximum distance of populations within a given region to still enable gene flow between them), long-term biomonitoring of representative habitats, information and awareness raising of the community (Haese, 1999), preservation of historic mine buildings and monuments (Wagenbreth, 1973; Philipp, 2000), and an integration of the post-mining landscape in tourist concepts (Slotta, 2003). A good example for such a comprehensive strategy is "the lead legacy" for the Peak District's lead mining heritage (Barnatt \& Penny, 2004).

Science still lacks coherent insight into the exact measures for restoration of metallophyte communities. At present it is quite impossible to predict the long-term influence of climate change and the still-rising atmospheric nitrogen deposition on diversity of the biocenoses on metalliferous sites which are limited in water and nutrients.

Research into the geographic distribution, ecological amplitude and niche differentiation of metallophytes, and the impact of ecological management and habitat alteration on metallophyte vegetation, is necessary to facilitate conservation and to develop and manage sites in the future. A successful realization of these points needs an intensive interdisciplinary knowledge-sharing between science and site management. This is realized for example in the "European Heavy Metal Ecology Network" (EHMEN: www.postmining-ecosystems.org) which is made up of a large group of professionals from science, management and governments across Europe or the "Arbeitsgemeinschaft Bergbaufolgelandschaften e. V." (Working group post-mining landscapes: www.bbfl.de).

\section{Acknowledgment}

For language correction I would like to thank Janneke Sedlo. 


\section{References}

Baker, A. J. M.; Ernst, W. H. O.; Van der Ent, A.; Malaisse, F. \& Ginocchio, R. (2010): Metallophytes: the unique biological resource, its ecology and conservational status in Europe, Central Africa and Latin America, In: Ecology of Industrial Pollution, Batty, L. C. \& Hallberg, K. B., pp. 7-40, Cambridge, Cambridge University Press, UK

Banasova, V. (1980): Indikationseigenschaften der Kupferhalden-Vegetation in der Slowakei. Wissenschaftliche Beiträge Martin-Luther-Universität Halle-Wittenberg, Reihe P, Vol. 27, No.P11, pp. 74-76, ISSN 0440-1298

Barnatt, J. \& Penny, R. (2004): The Lead Legacy. The Prospects for the Peak District's Land Mining Heritage. Peak District National Park Authority, Buxton

Baumbach, H. (2000): Beitrag zur Flora und Vegetation von Bergbau-, Hütten- und Stollenhalden im Mansfelder und Sangerhäuser Revier. Schriftenreihe des MansfeldMuseum (Neue Folge), Vol.5, pp. 105-118, ISBN 3-932639-04-9

-(2005): Genetische Differenzierung mitteleuropäischer Schwermetallsippen von Silene vulgaris, Minuartia verna und Armeria maritima unter Berücksichtigung biogeographischer, montanhistorischer und physiologischer Aspekte. Dissertationes Botanicae Vol.398, pp. 1-128, ISBN 3-443-64311-6

-(2008): Zur Situation der Schwermetallrasen und ihrer Standorte im östlichen und südöstlichen Harzvorland. Naturschutz im Land Sachsen-Anhalt Vol.40, No.2, pp. 3-19

-(in prep.): Genetic differentiation of the central European Minuartia verna complex: molecular evidence for glacial relict endemism of metallicolous populations.

Baumbach, H. \& Hellwig, F. H. (2003): Genetic variation within and among metal-tolerant and non-tolerant populations of Armeria maritima (Mill.) Willd. s.l. (Plumbaginaceae) in Central and Northeast Germany. Plant Biology, Vol.5, No.2, pp. 186-193, ISSN 1435-8603

Baumbach, H. \& Hellwig, F. H. (2007): Genetic differentiation of metallicolous and nonmetallicolous Armeria maritima (Mill.) Willd. taxa (Plumbaginaceae) in Central Europe. Plant Systematics and Evolution Vol.269, No.3-4, pp. 245-258, ISSN 0378-2697

Baumbach, H. \& Schubert, R. (2008): Neue taxonomische Erkenntnisse zu den Charakterarten der Schwermetallvegetation und mögliche Konsequenzen für den Schutz von Schwermetallstandorten. Feddes Repertorium Vol.119, No. 5-6, pp. 543555, ISSN 0014-8962

Baumbach, H. \& Volkmann, H. (2002): Dynamik, genetische Struktur und Schutz kleiner Populationen - das Beispiel von Armeria maritima ssp. hornburgensis. Mitteilungen zur floristischen Kartierung in Sachsen-Anhalt Vol.7, pp. 3-24, ISSN 1432-8038

Baumbach, H. \& Volkmann, H. (2006): Zur Situation von Armeria maritima ssp. hornburgensis - aktuelle Daten zu Populationsgröße, Demographie und Taxonomie. Mitteilungen zur floristischen Kartierung in Sachsen-Anhalt Vol.11, pp. 41-50, ISSN 1432-8038

Baumbach, H.; Volkmann, H. \& Wolkersdorfer, C. (2007): Schwermetallrasen auf Hüttenstäuben am Weinberg bei Hettstedt-Burgörner (Mansfelder Land) - Ergebnis jahrhundertelanger Kontamination und Herausforderung für den Naturschutz. Hercynia N. F. Vol.40, No.2, pp. 87-109, ISSN 0018-0637 
Becker, T.; Brändel, M. \& Dierschke, H. (2007): Trockenrasen auf schwermetall- und nicht schwermetallhaltigen Böden der Bottendorfer Hügel in Thüringen. Tuexenia Vol.27, pp. 255-286, ISSN 1433-8440

Benkert, D.; Fukarek, F. \& Korsch, H. (1996): Verbreitungsatlas der Farn- und Blütenpflanzen Ostdeutschlands, ISBN 3-437-35066-8, Gustav Fischer Verlag, Jena, Germany

Bode, A. (1928): Reste alter Hüttenbetriebe im West- und Mittelharze. Jahrbuch der Geographischen Gesellschaft Hannover, pp. 141-197

Bröker, W. (1963): Genetisch-physiologische Untersuchungen über die Zinkverträglichkeit von Silene inflata Sm. Flora (Jena), Vol.153, pp. 122-156

Christiansen, W. (1931): Die mitteldeutschen Formenkreise der Gattung Armeria. Botanisches Archiv, Vol.31, pp. 247-265

Dejonghe, L.; Ladeuze, F. \& Jans, D. (1993): Atlas des Gisements plombo-zinciferes du Synclinorium de Verviers (Est de la Belgique). Toelichtende Verhandelingen Geologische en Mijnkaarten van België, Vol.33, pp. 1-483

Daniëls, F. \& Geringhoff, H. (1994): Pflanzengesellschaften auf schwermetallreichen Böden der Briloner Hochfläche, Sauerland. Tuexenia, Vol.14, pp. 143-150

Dierschke, H. \& Becker, T. (2008): Die Schwermetall-Vegetation des Harzes - Gliederung, ökologische Bedingungen und syntaxonomische Einordnung. Tuexenia, Vol.28, pp. 185-227, ISSN 1433-8440

Ellenberg, H. (1996): Vegetation Mitteleuropas mit den Alpen, $5^{\text {th }}$ edition, Verlag Eugen Ulmer, ISBN 3-8252-8104-3, Stuttgart (Hohenheim), Germany

Englisch, T.; Valachovič, M.; Mucina, L.; Grabherr, G. \& Ellmauer, T. (1993): Thlaspietea rotundifolii, In: Die Pflanzengesellschaften Österreichs. Teil II: Natürliche waldfreie Vegetation, Grabherr, G. \& Mucina, L., pp. 276-342, Gustav Fischer Verlag, Jena, Germany

Ernst, W. (1965): Ökologisch-Soziologische Untersuchungen der Schwermetall-Pflanzengesellschaften Mitteleuropas unter Einschluß der Alpen. Abhandlungen aus dem Landesmuseum für Naturkunde zu Münster in Westfalen, Vol.27, No.1, pp. 5-54: -(1966) Ökologisch-soziologische Untersuchungen an Schwermetallpflanzengesellschaften Südfrankreichs und des östlichen Harzvorlandes. Flora, Abt. B, Vol.156, pp. 301-318

-(1968): Der Schwermetallrasen von Blankenrode, das Violetum calaminariae westfalicum. Mitteilungen der floristisch-soziologischen Arbeitsgemeinschaft N. F., Vol.13, pp. 261-262

-(1974): Schwermetallvegetation der Erde, Gustav Fischer Verlag, ISBN 3-437-30187-X, Stuttgart, Germany

-(1976): Violetea calaminariae, In: Prodomus of the European Plant Communities. Vol. 3., R. Tüxen, pp. 1-132, J. Cramer, Vaduz, Switzerland

Ernst, W.; Knolle, F.; Kratz, S. \& Schnug, E. (2004): Aspects of ecotoxicology of heavy metals in the Harz region - a guided excursion. Landbauforschung Völkenrode, Vol.54, No.2, pp. 53-71

Freytag, M. (1870): Wissenschaftliches Gutachten über den Einfluß, welchen die Hüttenwerke der Mansfelder Kupferschieferbauenden Gewerkschaft in dem Wipperthal zwischen Mansfeld und Hettstedt auf die Vegetation der benachbarten Grundstücke und indirect auf Menschen und Thiere ausüben. Druck von Heinrich Reichardt, Eisleben, Germany 
Garcia-Gonzalez, A. \& Clark, S. C. (1989): The distribution of Minuartia verna and Thlaspi alpestre in the British Isles in relation to 13 soil metals. Vegetatio, Vol.84, pp. 87-98

Gerth, A.; Merten, D. \& Baumbach, H. (2011): Verbreitung, Vergesellschaftung und genetische Populationsdifferenzierung des Berg-Steinkrautes (Alyssum montanum L.) auf Schwermetallstandorten im östlichen Harzvorland. Hercynia N. F., Vol.44, No.1, pp. 73-92, ISSN 0018-0637

Golde, A. (2001): Schwermetallfluren - ein in Sachsen bislang verkannter Lebensraumtyp Überblick über Vorkommen und Ausbildungsformen im Freiberger Bergbaugebiet. Berichte der Arbeitsgemeinschaft Sächsischer Botaniker N. F., Vol.18, pp. 49-60 -(2011): Das Freiberger Bergbaugebiet, In: Bergbaufolgelandschaften Deutschlands geobotanische Aspekte und Rekultivierung, Baumbach, H.; Heinze, M. \& Sänger, H., in press, Weissdorn-Verlag, Jena, Germany

Graebner, P. (1919): Minuartia verna. Synopsis der Mitteleuropäischen Flora, Vol.5, No. 1, pp. 734-751

Graitson, E.; Melin, E. \& Goffin, M. (2003): Inventaire et caractérisation des sites calaminaires en Région wallonne. Société Publique d'Aide à la Qualité de l'Environnement G.I.R.E.A.- Université de Liège, Belgium

Gries, B. (1966): Zellphysiologische Untersuchungen über die Zinkresistenz bei Galmeiformen und Normalformen von Silene cucubalus Wib. Flora, Abt. B, Vol.156, pp. $271-290$

Haese, U. (1999): Der Schutz der Stolberger Schwermetallvegetation im Lichte des öffentlichen Bewußtseins. LÖBF-Schriftenreihe, Vol.16, pp. 129-137, ISBN 3-89174029-8

Haeupler, H. \& Schönfelder, P. (1988): Atlas der Farn- und Blütenpflanzen der Bundesrepublik Deutschland, Ulmer, ISBN 3-8001-3434-9, Stuttgart, Germany

Halliday, G. (1964): Studies in the Minuartia verna complex, I. Feddes Repertorium, Vol.69, pp. 8-14

Hayek, A. (1922): Versuch einer natürlichen Gliederung des Formenkreises der Minuartia verna (L.) Hiern. Österreichische Botanische Zeitschrift, Vol.71, pp. 89-116

Heimans, J. (1936): De Herkomst van de Zinkflora aan de Geul. Nederlandsch kruidkundig Archief, Vol.46, pp. 878-897

-(1961): Taxonomic, phytogeographical and ecological problems round Viola calaminaria, the zinc violet. Publicaties van het Natuurhistorisch Genootschap in Limburg, Vol.XII, pp. 55-71

Hellwig, M. (2002): Die Schwermetallbelastungen und die Schwermetallvegetation im Innerstetal. Berichte der Naturhistorischen Gesellschaft Hannover, Vol.144, pp. 3-21

Hildebrandt, U.; Hoef-Emden, K.; Backhausen, S.; Bothe, H.; Bozek, M.; Siuta, A. \& Kuta, E. (2006): The rare, endemic zinc violets of Central Europe originate from Viola lutea Huds. Plant Systematics and Evolution, Vol.257, pp. 205-222, ISSN 0378-2697

Huneck, S. (2006): Die Flechten der Kupferschieferhalden um Eisleben, Mansfeld und Sangerhausen. Mitteilungen zur floristischen Kartierung in Sachsen-Anhalt, Sonderheft 4, pp. 1-62, ISSN 1432-8038

Knolle, F. (1989): Harzbürtige Schwermetallkontaminationen in den Flußgebieten von Oker, Innerste, Leine und Aller. Beiträge zur Naturkunde Niedersachsens, Vol.42, No. 2, pp. $53-60$ 
Koch, K. (1932): Die Vegetationsverhältnisse des Silberberges im Hüggelgebiet bei Osnabrück. Mitteilungen des Naturwissenschaftlichen Vereins Osnabrück, Vol.22, pp. 117-149

Koch, M. \& Kuhn, L. (1989): Das Minuartio-Thlaspietum alpestris Koch 1932, eine Pflanzengesellschaft schwermetallhaltiger Böden im Hüggelgebiet, Landkreis Osnabrück. Osnabrücker naturwissenschaftliche Mitteilungen, Vol.15, pp. 137-154

Koch, M.; Mummenhoff, K. \& Hurka, H. (1998): Systematics and evolutionary history of heavy metal tolerant Thlaspi caerulescens in Western Europe: evidence from genetic studies based on isozyme analysis. Biochemical Systematics and Ecology, Vol.26, pp. 823-838

Lambinon, J. \& Auquier, P. (1964): La flore et la végétation des terrains calaminaires de la Wallonie septentrionale et de la Rhénanie aixoide. Natura Mosana, Vol.16, pp. 113-130

Lefebvre, C. (1985): Morphological variation, breeding system and demography at populational and subpopulational levels in Armeria maritima (Mill.) Willd. In: Genetic differentiation and dispersal in plants, Jacquard, P.; Heim, G. \& Antonovics, J., pp. 129-139, Springer, Berlin, Germany

Libbert, W. (1930): Die Vegetation des Fallsteingebietes. Mitteilungen der floristischsoziologischen Arbeitsgemeinschaft in Niedersachsen, Vol.2, pp. 1-66

Mattfeld, J. (1922): Geographisch-genetische Untersuchungen über die Gattung Minuartia L. (Hiern). Feddes Repertorium, Vol.LVII, No.Beiheft 127

Meusel, H.; Jäger, E. \& Weinert, E. (1965): Vergleichende Chorologie der zentraleuropäischen Flora. Kartenband. Gustav Fischer, Jena.

Mucina, L. (1993): Aspenietea trichomanis. In: Die Pflanzengesellschaften Österreichs. Teil II: Natürliche waldfreie Vegetation. Grabherr, G. \& Mucina, L., pp. 241-275, Gustav Fischer Verlag, Jena, Germany

Nauenburg, J. D. (1986): Untersuchungen zur Variabilität, Ökologie und Systematik der Viola tricolor-Gruppe in Mitteleuropa. Diss., Math.-Nat. FB, Georg AugustUniversität, Göttingen, Germany

Neumann, D.; zur Nieden, U.; Schwieger, W.; Leopold, I. \& Lichtenberger, O. (1997): Heavy metal tolerance of Minuartia verna. Journal of Plant Physiology, Vol.151, pp. 101-108.

Oertel, T. (2002): Untersuchung und Bewertung geogener und anthropogener Bodenschwermetallanreicherungen als Basis einer geoökologischen Umweltanalyse im Raum Eisleben-Hettstedt. Diss., Mathematisch-NaturwissenschaftlichTechnische Fakultät, Martin-Luther-Universität Halle-Wittenberg, Germany

Pardey, A. (1999a): Grundlagen des Naturschutzes auf Schwermetallstandorten in NRW. Abiotische Verhältnisse, Flora, Vegetation, Fauna, aktuelle Schutzsituation und zukünftige Zielsetzungen. LÖBF-Schriftenreihe, Vol.16, pp. 7-48, ISBN 3-89174-029-8

Pardey, A. (Ed.) (1999b): Naturschutzrahmenkonzeption Galmeifluren NRW. LÖBF Schriftenreihe, Vol.16, pp. 1-271, ISBN 3-89174-029-8

Pauwels, M.; Saumitou-Laprade, P.; Holl, A. C.; Petit, D. \& Bonnin, I. (2005): Multiple origin of metallicolous populations of the pesudometallophyte Arabidopsis halleri (Brassicaceae) in central Europe: the cpDNA testimony. Molecular Ecology, Vol.14, pp. $4403-4414$

Philipp, R. (2000): Denkmalpflegerische Aspekte der Haldenlandschaft des Kupferschieferbergbaus in Sachsen-Anhalt. Schriftenreihe des Mansfeld-Museums (Neue Folge), Vol.5, pp. 18-24, ISBN 3-932639-04-9 
Pinto da Silva, A. R. (1972): Armeria Willd. In: Flora Europaea Vol. 3: Diapensiaceae to Myoporaceae, Tutin, T. G.; Heywood, V. H.; Burges, N. A.; Moore, D. M.; Valentine, D. H.; Walters, S. M. \& Webb D. A., pp. 30-38, Cambridge University Press, ISBN 0521-08489-X, Cambridge, UK

Pott, R. \& Hellwig, M. (2007): Das Armerietum halleri Libbert 1930 aus dem Tal der Innerste am Nordrand des Harzes. Hercynia N. F., Vol.40, pp. 245-255

Punz, W. (1991): Zur Flora und Vegetation über schwermetallhaltigem Substrat im Ostalpenraum - Eine Übersicht. Verhandlungen der Zoologisch-Botanischen Gesellschaft in Österreich, Vol.128, pp. 1-18

-(1994): Schwermetallstandorte im mittleren Alpenraum und ihre Vegetation - neue Befunde. Verhandlungen der Zoologisch-Botanischen Gesellschaft in Österreich, Vol.131, pp. $1-26$

-(2008): Schwermetallstandorte und deren Vegetation im Land Salzburg. Biotopverbund - Lebensraumvernetzung \& Beiträge zum 13. Österreichischen Botanikertreffen: pp. 375-378

Punz, W. \& Mucina, L. (1997): Vegetation on anthropogenic metalliferous soils in the eastern Alps. Folia Geobot. Phytotax., Vol.32, pp. 283-295.

Punz, W.; Schinninger, R. \& Engenhart, M. (1990): Floristische Bearbeitungen von Schwermetallstandorten in der Steiermark - Eine Übersicht. Mitteilungen des naturwissenschafltichen Vereins für Steiermark, Vol.120, pp. 291-297

Pyšek, A. \& Pyšek, P. (1989): Vegetation der Abbaudeponien in Böhmen: Veränderung der Artenzusammensetzung im Verlauf der Vegetationsentwicklung. Verhandlungen der Gesellschaft für Ökologie, Vol.XVIII, pp. 37-41.

Pyšek, A. \& Stočes, I. (1978): Ein Beitrag zur Kenntnis der Vegetation an blei- und zinkreichen Biotopen in der Erz-Aureole des Massivs von Kladruby in Westböhmen. Folia Musei Rerum Naturalium Bohemiae Occidentalis, Geologica, pp. 1-16

Pyšek, P. \& Pyšek, A. (1988): Zur spontanen Begrünung der erzhaltigen und erzlosen Abbaudeponien in Böhmen. Preslia, Vol.60, pp. 133-155

Raskin, R. (2003): Sind Schwermetallfluren regenerierbar? Erste Ergebnisse einer Erfolgskontrolle im Raum Stolberg. LÖBF-Mitteilungen 3/03: pp. 18-22

-(2008): Möglichkeiten und Grenzen der Regeneration von Schwermetallfluren. Naturschutz und Freizeitgesellschaft, Vol.8, pp. 60-76, Academia Verlag, Aachen

Rothmaler, W. (1963): Silene cucubalus Wibel subsp. humilis (R. Schubert) Rothm. Feddes Repertorium, Vol.67, No.1-3, p. 4

Schat, H.; Kuiper, E.; Ten-Bookum, W. M. \& Vooijs, R. (1993): A general model for the genetic control of copper tolerance in Silene vulgaris: Evidence from crosses between plants from different tolerant populations. Heredity, Vol.70, No.2, pp. 142147

Schat, H. \& Vooijs, R. (1997): Multiple tolerance and co-tolerance to heavy metals in Silene vulgaris: A co-segregation analysis. New Phytologist, Vol.136, No.3, pp. 489-496

Schat, H.; Vooijs, R. \& Kuiper, E. (1996): Identical major gene loci for heavy metal tolerances that have independently evolved in different local populations and subspecies of Silene vulgaris. Evolution, Vol.50, No. 5, pp. 1888-1895

Schubert, R. (1953/54): Die Schwermetallpflanzengesellschaften des östlichen Harzvorlandes. Wissenschaftliche Zeitschrift der Martin-Luther-Universität HalleWittenberg, Math.-Nat., Vol.3, No.1, pp. 51-70 
-(1954a): Zur Systematik und Pflanzengeographie der Charakterpflanzen der Mitteldeutschen Schwermetallpflanzengesellschaften. Wissenschaftliche Zeitschrift der Martin-Luther-Universität Halle-Wittenberg, Math.-Nat., Vol.3, No.4, pp. 863-882 -(1954b): Die Pflanzengesellschaften der Bottendorfer Höhe. Wissenschaftliche Zeitschrift der Martin-Luther-Universität Halle-Wittenberg, Math.-Nat., Vol.4, No.1, pp. 99-120

-(2001): Prodromus der Pflanzengesellschaften Sachsen-Anhalts. Mitteilungen zur floristischen Kartierung in Sachsen-Anhalt, Sonderheft 2

Schubert, R.; Hilbig, W. \& Klotz, S. (2001): Bestimmungsbuch der Pflanzengesellschaften Deutschlands, Spektrum Akademischer Verlag, ISBN 3-8274-0915-2, Heidelberg, Germany

Schulz, A. (1912): Über die auf schwermetallhaltigem Boden wachsenden Phanerogamen Deutschlands. Jahres-Ber. Westfäl. Prov.-Ver. Wiss., Vol.40, pp. 209-227

Schwarz, O. (1949): Beiträge zur Nomenklatur und Systematik der mitteleuropäischen Flora. Mitteilungen der Thüringischen Botanischen Gesellschaft, Vol.1, No.1, pp. 98-99

Schwickerath, M. (1931): Das Violetum calaminariae der Zinkböden in der Umgebung Aachens. Eine pflanzensoziologische Studie. Beiträge zur Naturdenkmalpflege, Vol.14, pp. $463-503$

Simon, E. (1975): La dynamique de la végétation de quelques sites métallifères dans les régions d'Eupen et d'Aix-la-Chapelle en relation avec les facteurs édaphiques. Bulletin de la Société Royale de Botanique de Belgique, Vol.108, pp. 273-386, ISSN 05838819

Slotta, R. (2003): Die Mansfelder Kupfer-Straße - Chance oder Utopie? Der Anschnitt, Vol.55, No.3-5, pp. 224-235, ISSN 0003-5238

Thal, J. (1588): Sylva Hercynia. Frankfurt am Main.

van der Ent, A. (2007): Kansen voor herstel van zinkflora in het boven-Geuldal. De Levende Natuur, Vol.108, No.1, pp. 14-19

Vekemans, X.; Lambert, A. \& Lefebvre, C. (1992): Isozyme variation at the populational level in Armeria maritima. Belgian Journal of Botany, Vol.125, No.2, pp. 270-275

Vekemans, X. \& Lefebvre, C. (1997): On the evolution of heavy-metal tolerant populations in Armeria maritima: Evidence from allozyme variation and reproductive barriers. Journal of Evolutionary Biology, Vol.10, No.2, pp. 175-191

Wagenbreth, O. (1973): Zur landeskulturellen Erhaltung von Bergbauhalden. Geographische Berichte, Vol.68, No.3, pp. 196-205

Wallroth, F. W. (1842): Monographischer Versuch über die Gewächs-Gattung Armeria Willd. Beiträge zur Botanik, Vol.1, No.1, pp. 168-218

Wein, K. (1926): Die Beziehungen zwischen Erzvorkommen und Pflanzenverbreitung in Deutschland. Der Naturforscher, Vol.3, No.5, pp. 240-243

Whiting, S. N.; Reeves, R. D.; Richards, D.; Johnson, M. S.; Cooke, J. A.; Malaisse, F.; Paton, A.; Smith, J. A. C.; Angle, J. S.; Chaney, R. L.; Ginocchio, R.; Jaffre, T.; Johns, R.; McIntyre, T.; Purvis, O. W.; Salt, D. E.; Schat, H.; Zhao, F. J. \& Baker, A. J. M. (2004): Research priorities for conservation of metallophyte biodiversity and their potential for restoration and site remediation. Restoration Ecology, Vol.12, No.1, pp. 106-116 
Wierzbicka, M. \& Panufnik, D. (1998): The adaptation of Silene vulgaris to growth on a calamine waste heap (S. Poland). Environmental Pollution, Vol.101, No. 3, pp. 415426

Wisskirchen, R. \& Haeupler, H. (1998): Standardliste der Farn- und Blütenpflanzen Deutschlands, Verlag Eugen Ulmer, ISBN 3-8001-3360-1, Stuttgart (Hohenheim), Germany 


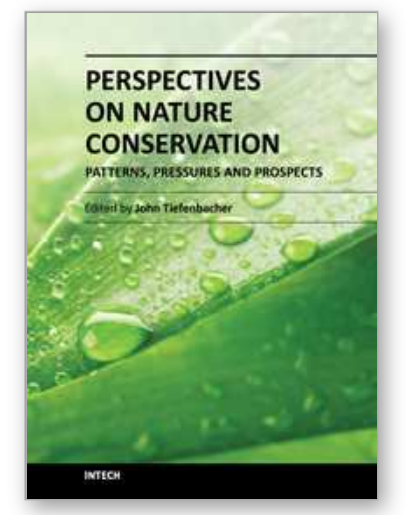

\author{
Perspectives on Nature Conservation - Patterns, Pressures and \\ Prospects \\ Edited by Prof. John Tiefenbacher
}

ISBN 978-953-51-0033-1

Hard cover, 270 pages

Publisher InTech

Published online 29, February, 2012

Published in print edition February, 2012

Perspectives on Nature Conservation demonstrates the diversity of information and viewpoints that are critical for appreciating the gaps and weaknesses in local, regional and hemispheric ecologies, and also for understanding the limitations and barriers to accomplishing critical nature conservation projects. The book is organized to emphasize the linkages between the geographic foci of conservation projects and the biological substances that we conceptualize as "nature", through original research. The reader moves through perspectives of diminishing spatial scales, from smaller to larger landscapes or larger portions of the Earth, to learn that the range of factors that promote or prevent conservation through the application of scholarship and academic concepts change with the space in question. The book reflects disciplinary diversity and a comingling of science and social science to promote understanding of the patterns of, pressures on and prospects for conservation.

\title{
How to reference
}

In order to correctly reference this scholarly work, feel free to copy and paste the following:

Henryk Baumbach (2012). Metallophytes and Metallicolous Vegetation: Evolutionary Aspects, Taxonomic Changes and Conservational Status in Central Europe, Perspectives on Nature Conservation - Patterns, Pressures and Prospects, Prof. John Tiefenbacher (Ed.), ISBN: 978-953-51-0033-1, InTech, Available from: http://www.intechopen.com/books/perspectives-on-nature-conservation-patterns-pressures-andprospects/metallophytes-and-metallicolous-vegetation-evolutionary-aspects-taxonomic-changes-andconservational

\section{INTECH}

open science | open minds

\section{InTech Europe}

University Campus STeP Ri

Slavka Krautzeka 83/A

51000 Rijeka, Croatia

Phone: +385 (51) 770447

Fax: +385 (51) 686166

www.intechopen.com

\section{InTech China}

Unit 405, Office Block, Hotel Equatorial Shanghai

No.65, Yan An Road (West), Shanghai, 200040, China 中国上海市延安西路65号上海国际贵都大饭店办公楼 405 单元

Phone: +86-21-62489820

Fax: +86-21-62489821 
(C) 2012 The Author(s). Licensee IntechOpen. This is an open access article distributed under the terms of the Creative Commons Attribution 3.0 License, which permits unrestricted use, distribution, and reproduction in any medium, provided the original work is properly cited. 